\title{
Mission (Im)Possible? \\ Cross-Gendered Shakespeare on Czech Stages after 1989
}

Ivona Mišterová

\begin{abstract}
This essay examines the theatrical practice of cross-gender casting with a focus on three selected productions of Romeo and Juliet staged by the Petr Bezruč Theatre in Ostrava (2011, director Anna Petrželková), the NaHraně Theatre in Prague (2012, director Jan Frič), and the Činoherní Studio Ústí nad Labem (2012, director Filip Nuckolls).
\end{abstract}

\section{Key words}

William Shakespeare, cross-gender casting, cross-gender dressing, doubling, Romeo and Juliet, reception 


\section{Regendered Shakespeare}

It was commonplace in Shakespeare's time that male actors played the roles of women. However, as Michael Shapiro observes, an all-male physical presence on stage probably questioned the 'stability of gender roles, generally described as male assertiveness and female submissiveness' (SHAPIRO 1996: 37). Thus, on stage, male actors created a theatrical construct of femininity which was grounded in the socially constructed femininity from which the conventional perception and understanding of femininity emerged. As Stephen Orgel (1996: 153) puts it, boy actors had to be first theatrically translated into women and subsequently women had to be translated into boys.

The theatrical convention of all-male casting was revived almost four hundred years later, when the National Theatre in London produced As You Like It with an all-male cast in 1967 (for more information on Rosalind's disguise in the text of the play, see DRÁBEK 2019). Simultaneously, the changing performative conventions in the late 1960s and early 1970s along with the second wave of feminism introduced the concept of gender as a social construct made up of learned values and beliefs, and more frequent experiments with the representation of gender on stage and screen were encouraged. By the 1990s, the idea that gender is performative rather than innate was not uncommon, and theatre audiences were not surprised by the concept that gender may be perceived as a cultural construct and sexual desire may be dependent on forces other than biological ones. This idea resonates with Judith Butler's theories on performativity. Emphasising that gender is performative, Butler at the same time suggests that gender is not biologically fixed but is socially constructed (BUTLER 1993: 12-13). She illustrates the disruption of the fixity of gender roles and sex/gender identities with such examples as cross-dressing, drag, and butch/femme identities.

The practice of cross-gender casting opens up a new space for the presentation and interpretation of gender since, as Laurence Senelick observes, "the man playing woman and woman playing man are the ultimate tease, being at the same time more and less than what they seem' (SENELICK 2000: 9). Naturally, there are a variety of opinions on cross-gender casting, just as a variety of terms have emerged to label this theatrical practice, especially when discussing female-to-male cross-casting (KLETT 2009: 3). To avoid ambiguity, the term cross-casting will be used in this article to refer to both female-to-male and male-to-female casting.

Although cross-gender casting experienced a boom in the Anglophone world in the 1990s, it was almost non-existent in Czechoslovakia and since 1993 the Czech Republic. However, it is important to note that a cross-gender current runs through European (including Czech) theatre history: in comical opera and operetta, the tradition of the breeches role (e.g., Cherubino in Mozart's Figaro's Wedding). Cross-gender conventions also registered in serious genres: e.g., Beethoven's Fidelio and Smetana's Dalibor. In terms of drama, several cross-gender cast performances were produced in the $20^{\text {th }}$ century, but, broadly speaking, they were very rare. In fact, they are still uncommon today. The history of the Czech cross-casting of Shakespeare's tragedies goes back to the second half of the $20^{\text {th }}$ century. In 1975, Jan Grossmann combined cross-gender casting 
with doubling in the production of King Lear, which was staged at the Cheb Theatre and in which Libuše Holečková played both Cordelia and the Fool. Grossmann's production probably inspired the Czech director and actor Oto Ševčík, who (cross-)cast Ilona Vaňková in the roles of Lear's youngest daughter and the Fool in 1988 at the J. K. Tyl Theatre in Pilsen (MIŠTEROVÁ 2013: 173). More than two decades later, theatre director and teacher Jan Nebeský employed the same strategy, casting Kateřina Winterová in both roles, emphasising a similarity between the characters. According to one Czech theatre critic, Winterová's Cordelia and the Fool resembled sad clowns tied to each other with unidentifiable chains, which was indicated by the prison uniform worn by both of them when accompanying Lear (MACHALICKÁ 2011). This interpretation resonates with Terence Hawkes's idea that Cordelia and the Fool are the same person (HAWKES 2005: 168). It is, however, conceivable that the director's cross-cast intention was an echo of his previous production of Hamlet (1994) in which he regendered the role of the gravedigger into a woman. Here the gravedigger was enacted by Zdena Hadrbolcová, an experienced actress and a member of the Comedy Theatre in Prague who was 57 years old at the time. As part of the theatre cycle called God Save Shakespeare, theatre director and playwright David Drábek revolutionised Richard III, turning it into a political cabaret and cross-casting Pavlína Štorková in the role of the last York and Plantagenet king at the Klicpera Theatre in 2012. The director visually emphasised a relationship between Richard's outer appearance and his immoral nature, with Štorková's king emerging as an embodiment of evil. His unscrupulous character was underscored by an exaggerated hunch, red skin peeling off the king's misshapen hands, a short black greasy fringe, a long plait which occasionally served as a whip, and last but not least, a leopard skin cloak resembling the war dresses of African chief warriors and dictators (Fig. 1).

Štorková's usurper of the throne was surrounded by male actors in Shakespeare's female roles, which had a comic effect particularly due to the larger, manly builds of the actors, some of whom wore beards. Conversely, Shakespeare's male roles were impersonated by slim male actors who used affectionate, narcissistic gestures. The dandyish Buckingham was thus permanently called Beckham (RESLOVÁ 2012). In addition, a popular Czech catch phrase 'so definitely' (tak určitě), which was originally used by Czech ice-hockey players at the World Championship in Bratislava in 2011 and heavily mocked by stand-up comedians, was repeated by the noble British lords as they began their lines of dialogue. The production was imbued with multiple allusions to England and Englishness and accompanied by live music, or more precisely, by famous songs originally performed by Elton John (Made in England), Queen (We Are the Champions), and the Beatles (Michelle), the last of which was sung by the victorious Richmond. Moreover, the well-known song Over the Rainbow, originally performed by Judy Garland in The Wizard of $\mathrm{Oz}$ in 1938, was heard offstage as sung by Richard during the scene of the murder of the young princes in the Tower (Richard III 4.2), thereby suggesting that they would find happiness in the afterlife. Richard's plaintive sentimental solo showed the ease with which the king could manipulate others. It is probably not by chance that the production was subtitled 'On the Power of the Powerless', referring to the 


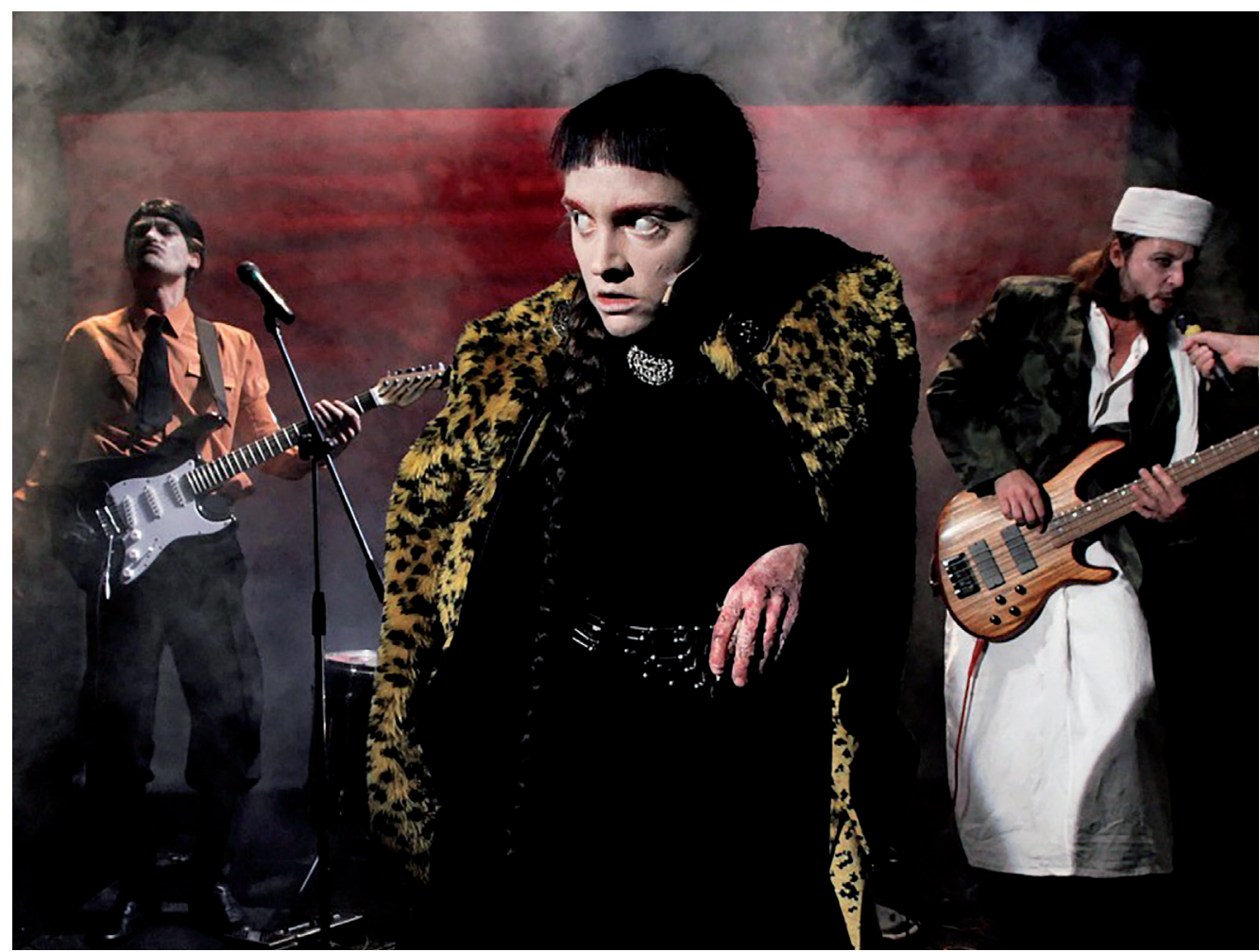

Fig. 1: Richard III (Pavlína Štorková) with a music band in the background.

Photographed by Patrik Borecký, and reproduced courtesy of the Klicpera Theatre.

eponymous essay written by Václav Havel in 1978 and dedicated to the Czech dissident philosopher and spokesperson for Charter 77 Jan Patočka, who had died a year earlier during a week-long interrogation by the state police.

This small sampling of Czech cross-gender cast performances shows that, while they are beginning to appear, they are still quite far from being frequent, let alone mainstream. It is not surprising, then, that no single-sex production or cross-cast production of Romeo and Juliet was staged until the second decade of the $21^{\text {st }}$ century. This essay examines three Czech productions of Romeo and Juliet from the 2010s: Anna Petrželková's Romeo and Juliet staged at the Petr Bezruč Theatre in Ostrava in 2011, Jan Frič's Romeo and Juliet and What? produced at the OntheEdge Theatre in Prague in 2012, and Filip Nuckolls's Romeo and Juliet, which was produced by the Činoherní Studio in Ústí nad Labem in 2012. What links these three productions is the practice of female-to-male/male-to-female cross-casting. What differentiates them are their particular ways of deploying cross-gender casting. Whereas Petrželková regendered the roles of the Nurse and Prince Escalus, Frič cross-cast only the role of the Nurse. Nuckolls produced Romeo and Juliet with an all-male cast, though, as he emphasised, without any sexual statement. In looking at these three performances, three fundamental questions 
arise. First, why did the directors apply cross-gender casting? Second, how (if at all) did cross-casting undermine the traditional/conventional perception of gender roles in the play? And third, did the character of the enacted dramatis persona change along with the gender of the actor/actress?

\section{Juliet's nurse is a man!}

Characterised by a number of innovatory elements, the first cross-gender cast production of Romeo and Juliet was directed by Anna Petrželková at the Petr Bezruč Theatre in Ostrava in 2011. The director transferred the conflict between two quarrelling families to a uniform block of flats in the 1990s. A clear reference to the post-Velvet Revolution period was accentuated by the use of numerous contemporary items, including household equipment and appliances. A special role was assigned to multifunctional sectional furniture, which served both as a habitat and as a locus communis of the protagonists.

The director made use of cross-gender casting for the roles of the Nurse (Norbert Lichý) and Prince Escalus (Sylvie Krupanská), which added a specific, though not erotically charged, flavour to the production. Prince Escalus, the wise ruler of Verona, symbolising law and order, was, in compliance with the temporal and spatial relocation, transformed into a gender-reversed figure of a caretaker who functioned as an embodied deus ex machina. Not only did she hold the highest position in the social hierarchy of the prefab, but she also represented a considerable threat to those who disobeyed her orders. Certain elements of comic irony in her interventions (obvious particularly in Romeo and Juliet 1.1 and 3.1) were enhanced by her appearance (see Fig. 2). Dressed in practical clothes and androgynous loafers, apparently intended for home wear, she gave the impression of a hard-working woman. There seemed to be a touch of suffering in her look as she walked to the centre of the stage, or more precisely into the Capulets' living room; she was holding a shovel and wearing knee-length elastic compression stockings, under which large varicose veins were painted, probably to further underscore a neglect for her own physical attractiveness or a lack of quality medical health care. Given her power and authority, she remotely resembled a stereotypical Socialist woman who had mastered men's skills and took an active part in public life. Her force majeure in a neighbourhood squabble (Romeo and Juliet 1.1) was accentuated by an uncompromising facial expression, suggesting she had no mercy for rule-breaking. Nevertheless, her authoritative interventions did more harm than good, as was obvious from the Capulets' and Montagues' surprised and shocked looks. It clearly produced strong negative emotions, which intensified the conflict and resulted in the 'bloody fray' (Romeo and Juliet 3.1.151).

The cross-gender casting of Prince Escalus and the Nurse naturally forced the audience to perceive the production in a new way. Crossing gender boundaries, the director redefined the existing world and in part freed it from gender stereotypes. The production thus challenged the conventional perception of gender in the play. Women were assigned a more decisive and aggressive role, whereas men slipped into a less 


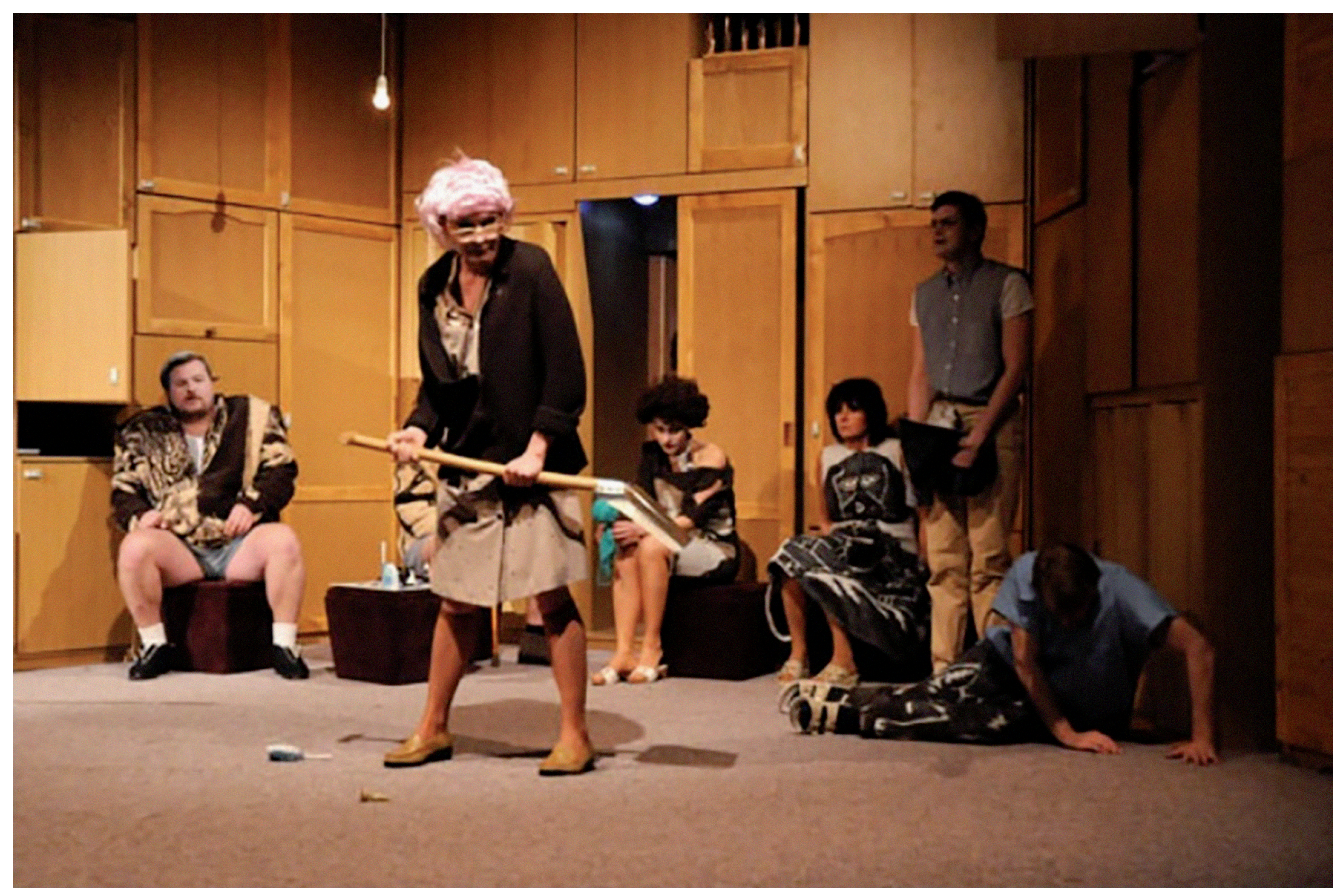

Fig. 2: Prince Escalus (Sylvie Krupanská) breaks up the fight between the Capulets and the Montagues. Photographed by Tomáš Ruta, and reproduced courtesy of the Petr Bezruč Theatre.

traditional, more caring, and consensual position. Here it is necessary to point out that both Sylvie Krupanská and Norbert Lichý were natural and spontaneous and had no tendency to overplay their roles.

However, it would be wrong to assume that traditional gender stereotypes were completely eliminated through this gender swap. They were communicated through the text of the play. In the role of the Nurse, Norbert Lichý did not lack warm and protective feelings, understanding, or charisma. Yet the masculine element echoed with a certain cacophony of otherness, making the assumed intimate closeness between the adolescent Juliet and her foster mother less plausible. Though this discordance may be viewed as an intended comic effect, it destroyed the concept of femininity and sexuality represented by Juliet, her mother, and the Nurse. As Theresa D. Kemp (2010: 92) notes, Juliet's sexuality is contrasted with that of her mother and her nurse, which was in this case satirised by the male cast. In this respect, the textual femininity blurred with the physical masculinity, thus creating a specific gender construct which oscillated between female subordination and male dominance.

A male cast member in the essentially female role of the Nurse may be seen either as a partial return to the Elizabethan stage or as a challenge to a traditional interpretation of this role. Due to the physique of the actor (see Fig. 3), the pattern of gender-reversed roles served partly as comic relief interwoven into the fundamentally tragic fabric. 


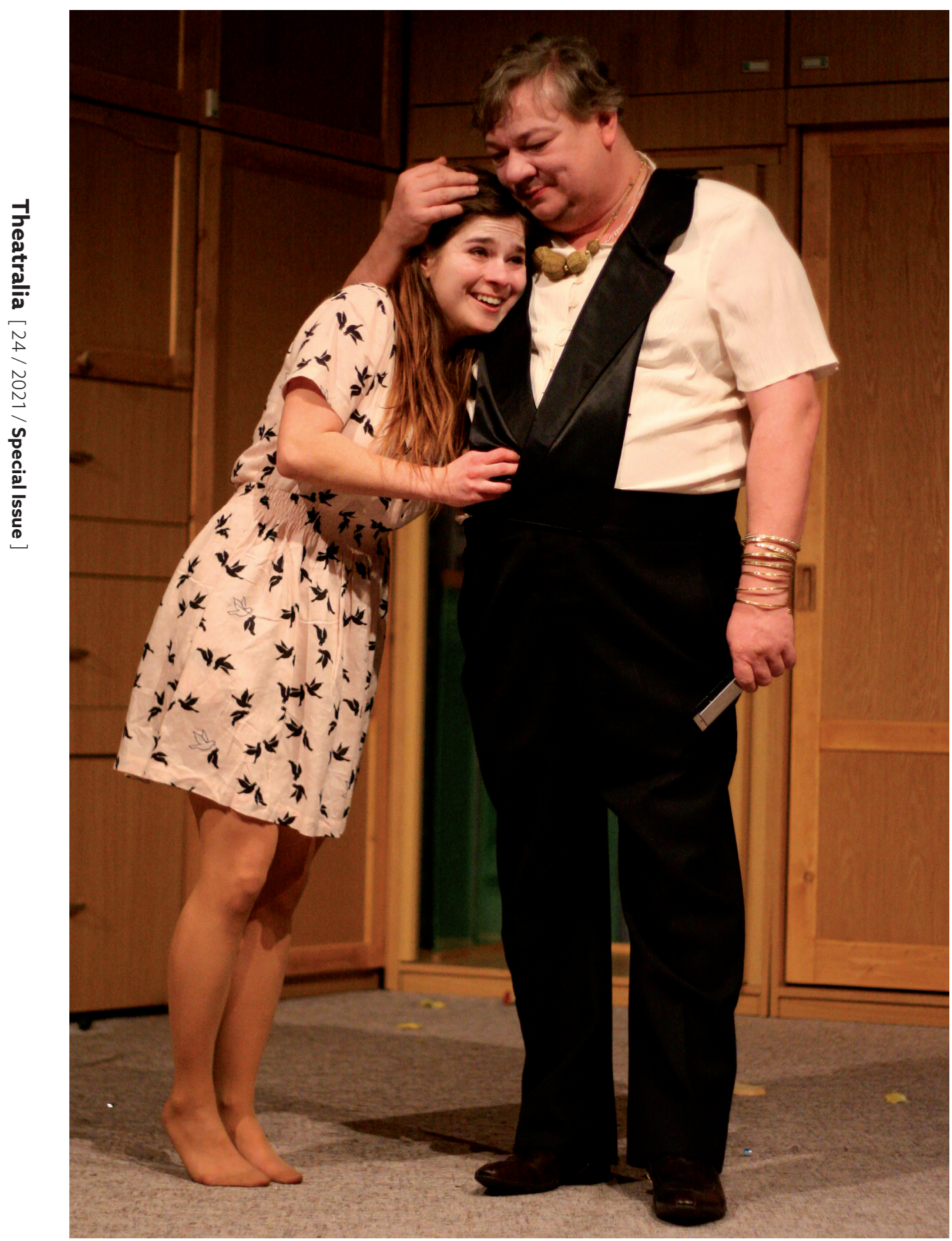

Fig. 3: The Nurse (Norbert Lichý) comforting Juliet (Pavla Sedláčková). Photographed by Tomáš Ruta, and reproduced courtesy of the Petr Bezruč Theatre. 


\section{'It Dawns for the World and It Grows Dark for Us'}

Another cross-gender performance of the play entitled Romeo and Juliet and What? was staged in 2012 by the NaHraně Theatre [OntheEdge Theatre] in Prague in Josef Topol's translation. The NaHraně Theatre was founded in 2009 by recent graduates of the DAMU Drama Theatre Department. The ensemble places emphasis on an interpretive acting theatre based on a dramatic text in a strategy which is considered to be the basis of a production. The company's repertoire includes mainly post-war British drama, e.g., Stoppard, Orton, and Penhall.

In cooperation with the dramaturg Ondřej Novotný, known for his poetic and lyrical style, the young director Jan Frič remade Shakespeare's tragedy and created a distinctive theatrical form, centring on poetry and the traditional themes of youthful passions and emotions. He transformed the play into a contemporary exploration of the pitfalls of young love. The poetic significance of the performance was accentuated by the poems of Czech poets Vladimír Holan and Jáchym Topol and of the American poet Diane di Prima, which accompanied and supplemented Shakespeare's verses, as well as by the production's subtitle, Or, It Dawns for the World and It Grows Dark for Us. The director's choice to amend the original title had two effects: firstly, it provided an insight into the classical nature of the play through the lens of the contemporary young generation, or more precisely, teenagers ('and What?'). Secondly, it emphasised the almost mythical scene of Romeo and Juliet's wedding night which they spend together as husband and wife and which is marked by the fear of light since it forces Romeo to leave: 'More light and light, more dark and dark our woes' (Romeo and Juliet 3.5.36). The contrast between dawn and dusk, or rather light and dark, to which the subtitle refers, recurs at the end of the performance, where it is transformed into the contrast between life and death.

As the director specified, Romeo and Juliet's wedding night was the most important segment of the performance, around which the whole story was centred. In this sense, the couple's transition to adulthood was depicted as a more or less hopeless inner struggle of an individual to adapt to and accept the harsh reality of the world. According to the director, '[The most important thing for Romeo and Juliet is] to run away with a beloved one, to run away from everyone and especially from here [...]' (Frič quoted in KONÍČKOVÁ 2012). ${ }^{1}$

The director proposed a new interpretation of the well-known play and imbued the performance with purely contemporary implications. Along with the dramaturg, Frič essentially cut the text and amended it with Holan's, Topol's, and di Prima's poems. He also substantially reduced the number of characters. On an almost bare stage, he thus directed a cast of only five actors, including experienced guest performer Vladimír Marek. Despite the limited size of the cast and considerable cuts, the director managed to stage the play almost in its entirety. Moreover, he used a rather unusual but functional doubling. Vladimír Marek's doubling of Friar Lawrence with the Nurse thus 


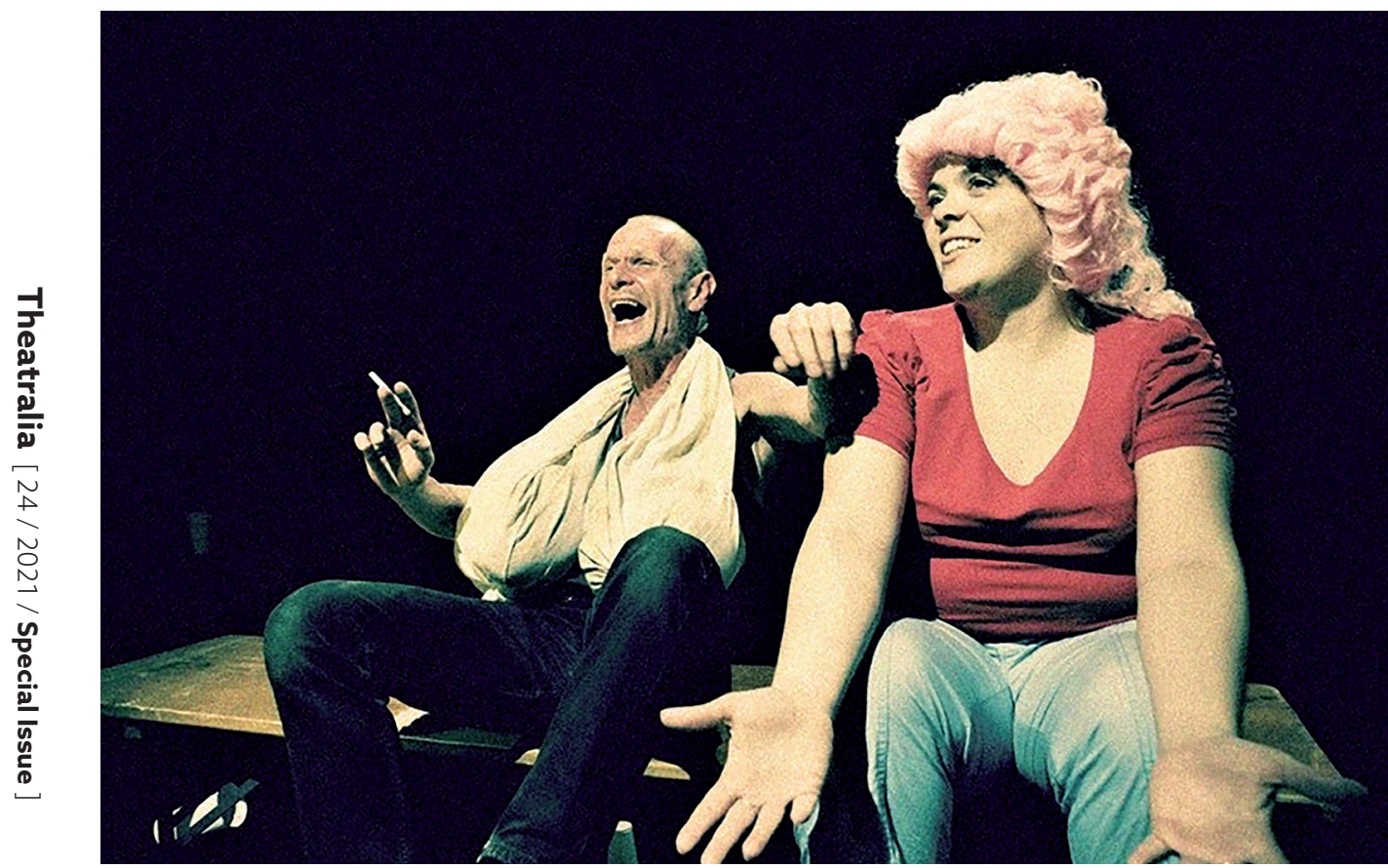

Fig. 4: Juliet (Lucie Polišenská) and the Nurse (Vladimír Marek).

Photographed by Patrik Borecký, and reproduced courtesy of the OntheEdge Theatre.

might not be read as simply a necessity of taking multiple parts (to save the company money), but rather as an attempt to show intergenerational interactions between the young couple and their non-biologically linked parent-like figures, who represent wisdom and experience, albeit each in a different form. Marek's Nurse was a Cimrmanlike, poetic, and somewhat comic figure ${ }^{2}$ the impression of whom was strengthened by two large white canvas bags hanging from his neck as a sign of the Nurse's femininity and a symbol of breastfeeding (see Fig. 4). However, his embodiment of the role of the Nurse, underscored with false saggy female breasts, did not result (at least in my view) in a drag-like show, but in an attempt to present a male standpoint through his female role. Similarly to the somewhat eccentric Nurse, his Friar Lawrence was a worldly man trying to help.

Marek not only managed to distinguish both characters by taking on/off the external attributes of femininity, he also managed to connect them conceptually. Consequently, the doubling of roles combined with cross-gender casting suggested that there was an intrinsically masculine element in the Nurse and, conversely, a feminine component in Friar Lawrence. Similarly, as in the case of the Nurse enacted by

2 Jára (da) Cimrman is a fictitious figure of Czech genius created by Jiří Šebánek, Zdeněk Svěrák, and Ladislav Smoljak in 1966. Cimrman was so popular in 2005 that he was voted 'the Greatest Czech of all time'. The result was, however, annulled due to Cimrman's non-existence. 
Norbert Lichý, the close relationship between Juliet and her Nurse, which is indicated in the text of the play, was to some extent deconstructed by means of an incongruous male component.

The play was adapted to a Czech context: it was set on wooden pub benches, with the main props - plastic beer cups painted with black skulls along with beer bottles, lighters, plush toys, and Barbie dolls. The location reminded one of a typical Czech beer boozer serving cheap drinks (KONÍČKOVÁ 2012). The shift from the environment of the wealthy Verona families to a contemporary Czech beer garden did not, however, devalue the text of the play. On the contrary, Shakespeare's words in Josef Topol's harsh but poetic translation transcended both time and space, delivering the same message in the $21^{\text {st }}$ century as at the time of its origin: love cannot be commanded.

\section{A return to the Elizabethan stage}

In December 2012, the young Czech director Filip Nuckolls in cooperation with the dramaturg Vladimír Čepek staged Shakespeare's tragedy with an all-male cast in Jiři Josek's translation at the Činoherní Studio Ústí nad Labem as a 'classical' addition to the theatre's repertoire. The text of the play was considerably cut, resulting in a dynamic ninety-minute performance. The concept for the production was to revive Elizabethan theatre conventions and retell Romeo and Juliet for a contemporary audience with male actors, though without homoerotic implications. According to the director, particular emphasis was placed on the spoken word, which served as a basis for the illusion (Nuckolls quoted in ČEPEK and NUCKOLLS 2013).

Nuckolls made use of a bare stage which consisted of two levels. The Elizabethan atmosphere was further underscored by almost sixty candles illuminating the stage, along with simple black and white timeless costumes which helped to differentiate between male and female characters. The actors playing male roles wore black suits, white shirts, and black ties, while those enacting female characters were dressed in long black skirts and were stripped to the waist. This natural (and somewhat non-sexual) halfnakedness without the use of outer female attributes emphasised the importance of the word and its meaning and encouraged the audience to employ their own imagination.

As the Divadelni noviny [Theatre Newspaper] reviewer notes, instead of a homoerotic interpretation, which might have been initially expected by critics and audiences, attention was focused on the 'straightforwardness, animality, and brutality', which were presented through seemingly economical yet highly effective duels and single combat swordfights choreographed by Václav Luks (KLÁR 2013: 6). The enmity between two quarrelling families was perceived as an archetypal conflict and a primitive instinct to kill. This primordial instinguo was approached in two ways: as a brutal evil disguised by the mask of arrogance and haughty manners, which characterised Jan Jankovskýs Tybalt, and as the hot-tempered clownish outbursts of Jiří Maryško's Mercutio. Embodied as a comic figure, Mercutio resembled a jocoserious character who was predictable in his nonchalance and 'martial scorn', just as Roy Eriksen (2015: 92) character- 


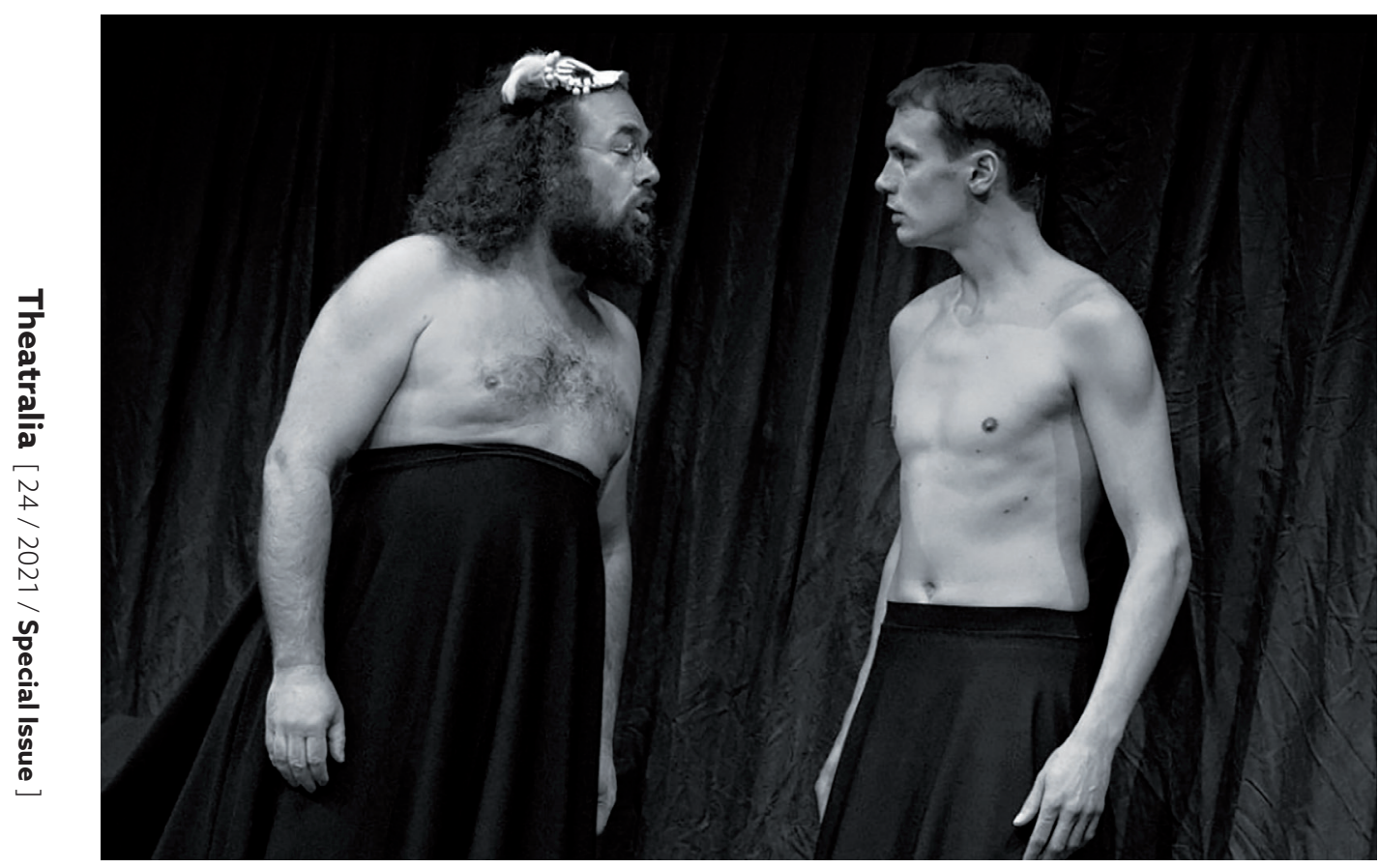

Fig. 5: The Nurse (Dan Dittrich) and Juliet (Vojtěch Kadeřábek). Photographed by Viktor Kronbauer, and reproduced courtesy of the Činoherní Studio Ústí nad Labem.

ises Romeo's best friend. Maryško's portrayal of Mercutio as an incurable clown thus served as a counterpoint to Jankovskýs rendition of Tybalt. Interpreting Mercutio's life as a joke-like metaphor, his violent death (Romeo and Juliet 1.3) thus resembled the improper resolution of this 'joke', followed by another chilling punchline in Tybalt's own death. In the trajectory of the performance, these demises simultaneously represented a prelude to the next tragic events that followed.

As mentioned, the text of the play was substantially cut, which caused the delayed entry of female characters on stage. Since a number of 'female' lines were deleted (in Lady Capulet and Lady Montague's lines in 1.1 and a conversation between Lady Capulet, the Nurse, and Juliet in 1.3), the first time Juliet, her mother, and the Nurse appear on stage is during the Capulet ball (Romeo and Juliet 1.5). The Nurse was played by Dan Dittrich, whose monumental Falstaff-like bearded figure was a constant source of laughter whenever the actor appeared on stage (see Fig. 5). Given the actor's physique and his comic potential, his male identity contrasting with that of the enacted female character stood out more than in the case of other actors impersonating women.

The Nurse and Friar Lawrence (Petr Panzenberger) substituted for Romeo and Juliet's parents, who were frequently absent from the home and limited their occasional parental activities to moralising and lecturing. Friar Lawrence and the Nurse shared not only a weakness for their protégés but also substance addiction: the Nurse imbibed in alcohol and Friar Lawrence smoked marijuana. However, these habits did 
not represent morally reprehensible behaviour, but were presented as a sign of their human weakness, suggesting that human beings (at least from time to time) yield to temptation.

\section{Conclusion: Mission almost Complete}

In all three cases, the reasoning behind the cross-gender cast was likely an effort towards an innovatory approach, which also essentially characterises all the mentioned theatre ensembles' approaches to staging. Apart from the pursuit of uniqueness, another factor that probably played a role in Petrželková's and Frič's male-to-female casting decisions was the wish to make the most experienced and best-known actor of the ensemble more visible. Nuckolls discussed his initial motivation behind the casting in an interview for a local newspaper, specifying that the idea for an all-male performance was born out of a promise given to the male members of the ensemble a long time before. Concomitantly, this was meant to revive the tradition of Elizabethan theatre, a goal which proved to be successful according to theatre critics who reviewed the production. Nevertheless, the choice of cross-gender casting also came about along with a greater awareness of gender issues at the beginning of the $20^{\text {th }}$ century, including the preparation of the first Czech anti-discrimination law, the adoption of which in 2009 can be seen as a major breakthrough.

The examination of the three productions reveals that cross-gender casting, particularly regarding the character of the Nurse, had a twofold effect. It served to undermine traditional perceptions of this character in the play as well as to provide comic relief, though the latter effect was rather the result of the actors' physique and of the use of stereotypical female attributes in Frič's production, which might have been seen as undermining the genre of tragedy. In Petrželková's staging, set in a typical post-Socialist flat in a housing estate and thus invoking images of the pre-1989 past, the detailed spatio-temporal allusions along with the cross-gender casting of the roles of the Nurse and Prince Escalus opened up new possibilities for the interpretation of the play. These had specific ramifications for the performance's exploration of gender, or rather of purely female and male roles, which thereby engagingly resonated with other disharmonious elements within the drama.

Interestingly enough, Petrželková underscored the Nurse's manliness through an (almost) black tie dress code. At first sight, there was no doubt that Juliet's Nurse was a man. Norbert Lichý, moreover, did not try to artificially feminise the role, which in result showed a balance between a masculine actor and an impersonated feminine character. In tune with the doubling of the Nurse and Friar Lawrence, Frič chose to dress Vladimír Marek in a gender neutral black T-shirt and black trousers, a costume design which also enabled the actor to switch easily between the enacted roles. The outer female attributes also served as a source of entertainment, particularly when the Nurse was describing how 'she' breastfed and weaned Juliet (1.3). In this case, there was no doubt that this Nurse was a man impersonating a woman. 
Marek's Nurse was visually feminised by means of false breasts, which were in contrast to the actor's obvious masculinity. Nuckolls differentiated between male and female roles within an all-male ensemble through straightforward cross-dressing underscored by long skirts as well as by partial nudity of the female characters. The effect was, however, not to provoke homoerotic allusions, but rather to suggest the blurring of gender boundaries.

As the theatre reviews show, all three productions were warmly received by critics and audiences (including the present author). Nevertheless, despite positive responses to these productions, cross-gender casting still appears less frequently than does traditional gender casting. The relative infrequency of engaging this theatrical practice in the Czech Republic may be rooted in the long history of traditional casting of male and female roles. This convention had stood out particularly in Socialist realist performances, which themselves can be connected to the traditional perception of gender roles which still seems to prevail in Czech society (FERBER and RAABE 2003). For these and other reasons, cross-gender casting that deconstructs and destabilises gender norms (sometimes politicising gender roles, as in the case of Štorková's Richard III) may be seen as unusual and threatening to some audiences.

Nevertheless, deconstructing normative gender roles on stage enables gender and dominant social paradigms to be cited and perceived in sometimes unexpected ways, thus embedded and often stereotypical presumptions can be dislodged in Czech audiences as well as in other environments. Although the emerging cross-gender performances do not necessarily serve to undermine the dominant gender system, they can help facilitate a discussion on gender and gender roles in the society. In the Czech Republic, the traditional gender role binary still persists despite the official repudiation of gender inequalities, notably through the Government Strategy for Equality of Women and Men in the Czech Republic for 2014-2020, launched in 2014. For both practitioners and audiences alike, theatre can offer unique opportunities to imagine and experiment with received perspectives, which is exactly what cross-gender performances encourage participants to do.

\section{Bibliography}

BUTLER, Judith. 1993. Bodies that Matter: On the Discursive Limits of 'Sex'. London: Routledge, 1993.

ČEPEK, Vladimír and Filip NUCKOLLS. 2013. 'Romeo padne, taktéž Julie. Ostatní to zabije' [Romeo will Fall Just Like Juliet. Others will be Killed]. Interview by Radek Strnad. Ústecký denik (29. 08. 2013). [accessed on 1.04.2020]. Available online at https://ustecky.denik.cz/ kultura_region/romeo-padne-taktez-julie-i-dalsi-to-zabije-20130829.html.

DRÁBEK, Pavel. 2019. Shakespeare's Myriad-Minded Stage: Propositional Spaces of Cultural Hybridity. Cahiers Élisabéthains 99 (2019): 1: 45-55. [accessed on 24.08.2020]. Available online at https://journals.sagepub.com/doi/full/10.1177/0184767819835551\#. 
ERIKSEN, Roy. 2015. Shakespeare as 'Chief Architect and Plotter': Romeo and Juliet and Civic Space. In Silvia Bigliazzi and Lisanna Calvi (eds.). Shakespeare, Romeo and Juliet, and Civic Life: The Boundaries of Civic Space. Oxford: Routledge, 2016: 82-99.

FERBER, Marianne A. and Phyllis Hutton RAABE. 2003. Women in the Czech Republic: Feminism Czech Style. International Journal of Politics, Culture and Society 16 (2003): 3: 407-430. [accessed on 26.08.2020]. Available online at https://link.springer.com/article/10.1023/A:1022308512580.

HAWKES, Terence. 2005. Shakespeare and the Reason: A Study of the Tragedies and the Problem Plays. New York and Abingdon: Routledge, 2005.

KEMP, Theresa D. 2010. Women in the Age of Shakespeare. Santa Barbara, CA: Greenwood/ABCCLIO LLC, 2010.

KLÁR, Petr KlariN [sic]. 2013. Muži sobě aneb Romeo a Julie [Men to Themselves, or Romeo and Juliet]. Divadelni noviny 22 (2013): 2: 6.

KLETT, Elizabeth. 2009. Cross-Gender Shakespeare and English National Identity: Wearing the Codpiece. New York: Palgrave Macmillan, 2009.

KONÍČKOVÁ, Olga. 2012. Romeo a Julie ... a co jako? aneb To světu svítá a stmívá se v nás [Romeo and Juliet and What?, or It Dawns for the World and It Grows Dark for Us]. Kultura 21 (9. 10. 2012). [accessed on 10.04.2020]. Available online at http://www.kultura21.cz/ divadlo/5252-romeo-a-julie-a-co-jako.

MACHALICKÁ, Jana. 2011. Král Lear v Národním: šifra Jana Nebeského [King Lear, or the Jan Nebeský Code] Lidovky (17. 11. 2011). [accessed on 22.09.2020]. Available online at https:// www.lidovky.cz/kultura/kral-lear-v-narodnim-sifra-jana-nebeskeho.A111115_103052_ln_kultura_btt.

MIŠTEROVÁ, Ivona. 2013. Angloamerické drama na plzeňských scénách. [Anglo-American Drama on Pilsen Stages]. Plzeň: University of West Bohemia, 2013.

ORGEL, Stephen. 1996. Impersonations: The Performance of Gender in Shakespeare's England. Cambridge: Cambridge University Press, 1996.

RESLOVÁ, Marie. 2012. Drama Richard III. jako černý kabaret s dobrým koncem [The Drama Richard III like a Cabaret with a Happy Ending]. Lidovky (4. 11. 2012). [accessed on 20.09.2020]. Available online at https://ceskapozice.lidovky.cz/recenze/drama-richard-iii-jako-cerny-kabaret-s-dobrym-koncem.A121101_123724_pozice_82177.

SENELICK, Laurence. 2000. The Changing Room: Sex, Drag and Theatre. London: Routledge, 2000.

SHAKESPEARE, William. 2000. Romeo and Juliet. Ed. by Jill L. Levenson. Oxford: Oxford University Press, 2000.

SHAPIRO, Michael. 1996. Gender in Play on the Shakespearean Stage: Boy Heroines and Female Pages. Michigan: University of Michigan, 1996. 


\section{PhDr. Ivona Mišterová, Ph.D.}

Department of English Language and Literature,

Faculty of Arts, University of West Bohemia in Pilsen

Sedláčkova 15

30614 Pilsen, Czech Republic

yvonne@kaj.zcu.cz

Ivona Mišterová is a senior lecturer at the Department of English Language and Literature at the University of West Bohemia in Pilsen, Czech Republic. She received her Ph.D. in English and American Literature from Charles University in Prague. Ivona has published monographs on performances of British and American works staged in Czech theatres in the $20^{\text {th }}$ and $21^{\text {st }}$ centuries (Anglo-americké drama na plzeňských scénách [Anglo-American Drama on Pilsen Stages], 2013, and Inter Arma non Silent Musae. Anglická a americká tvorba na českých moravských divadelních scénách v době první světové války [Inter Arma non Silent Musae. English and American Drama on Czech and Moravian Stages during the Great War], 2017). 
